\title{
IMPROVING YOUNG LEARNERS' INTEREST IN READING
}

\author{
Anak Agung Istri Bulan Fitria Dewi, Ni Ketut Riska Dewi Prawita \\ English Education Department \\ Faculty of Dharma Acarya \\ Institute of Hindu Dharma Negeri \\ Email: bulan.luminous@gmail.com, prawita_riska@yahoo.com
}

\begin{abstract}
The aim of this study is to enhance the young learners to make them interest in reading the books by several methods. These methods may help to increase the self-interest in reading. In globalization era, the development of the teaching and learning of English has been transformed. Nowadays, learners should not only focus on the learning of speaking and writing but also reading due to requirements of education that they should be able to understand and respond to the texts. There are many reasons the young learners have less interesting in reading, for example the development of the information forces the focus of teaching and learning on the critical reading. The most common thing is the students may not know their interest in reading before they start to read the books. Reading interests play a very important role in reading instruction and improvement. Furthermore, the understanding of young learners' interest and abilities is required to help them in reading. This article entitled Improve Young Learners' Interest in Reading consists of the great way of method to encourage the young learners to read through the use of wall magazine, the use of flash card, and the use of humor that can applied in strategies of reading aloud, reading the book several times, reading favorite books, and show many picture books.
\end{abstract}

Keywords: Reading interest, Young learners, Wall Magazine, Flash Card, Humor

\section{INTRODUCTION}

There is a way to get information from something written by someone and it is reading. It also happens in education, reading is one of the keys to improve the quality of education so that the knowledge of human resources can also be increased. Thus, the reading habits can be cultivated, nurtured and developed. Books as a medium for transformation and dissemination of knowledge can penetrate the geographical boundaries of a country, so that science can be communicated and quickly used in different parts of the world. Therefore, there is phrase said that book is the window of the world. In a society, some children don't like to read because they find books that are not interesting. It is well known that motivating students to read by providing interesting text is one of the effective reading programs. Reading can be done by experiencing. If these things happen children will not read anything and then reading will not be a fun activity for them.

The big challenge for teachers is not as simple as asking students to read - it's getting them to enjoy it too. Children will open the book during 
the lessons, but will they open another book when they get home at the end of the day? The National Literacy Trust described that based on developing a deep love of in reading books becoming a lifetime for the reader. The research has shown clearly that motivation of reading a book will be decreased by the ages, especially for the children attitudes towards reading become a less positive thing for them. Thus, when children do not enjoy reading since they are young, they will be unlikely to do so when they get older. However, for younger readers, in particular, home becomes the environment important places for them. Home is the most massive influence for the children, the supporting and understanding from the parents becomes a big key to develop their children reading interest. However, if the children do not see the member of the family like to read at home, they might be harder to instill their idea of reading. So, what can the teachers do to help the student encourage themselves in reading?

Understanding how a student interest in literacy affects their understanding of reading, it's the big thing for teachers in order to teach and assess the students inappropriately. To understand how the children, learn to be a good reader and comprehend the information that they read, thus the teachers must understand how they are interacting with the first print. The strong incentive to someone to read which is characterized by showing an interest in a variety of symbols that might appear interested in reading. The soul that could drive someone to do something and reading is the tendency of reading interest. A strong desire to read is indicated by reading interest. It is because reading is one of the important factors to help the children ready in reading. People interest to appear by the influenced of several factors, such as proposed by Crow and Crow in Supriyadi (1985:75) that there are four factors that offer the effect of people interest in reading, they are:

First, from the physical condition. The physical condition becomes the main focus because by the healthy and good physical condition than the state of children be able to stable. That will also affect the activity, such as reading a book. If the physical condition is healthy, then they will feel happy and enjoy to read.

Second, the mental condition. It is quite similar to the physical condition; the mental condition of children also really effects of their daily activities. If the mentally of the children "down" ("fall"), then the will not respond well in what they will do, such as reading a book. Conversely, if the student's mind is "good", then he will feel enthusiastic and enjoy to do the reading.

Third, from the emotional status. It is similar to the physical and mental condition; emotional status also affects the condition of the children individually. If the condition of the children is stable and in emotions, they will be excited about doing the activity that they wanted to do, like reading books. However, when the children emotions were unstable, then the children were also reluctant to do any activities like reading. 
Fourth, from the social environment. The social environment of children is definitely will be different. If the social environment in which the children live in surroundings, in the sense of the most community that likes to read, the children indirectly will begin to love reading too. However, if the children surroundings are not healthy enough, in the sense of the condition of society become unorganized, then it will also be a big effect by a shamble and unwilling to carry out the beneficial activities in reading a book.

From the four factors above, it can be concluded that the physical, mental, emotional, and social environment becomes a significant effect for the children. With healthy and good the physical, mental, emotional, and the social environment, then children will be satisfied to perform their activities that are very useful and also could broaden their own knowledge, such as reading and enhance the students reading interest will increase.

The decrease in students reading activity might be influenced by the information technology that very advanced. The variety of entertainment media that do not include books, it becomes more interesting for the children because reading books requires special attention that cannot be interrupted with any other activities. To get information instantly or through the conversation becomes a stronger tendency to seem than received the information from the text only. In addition, the young generation todays are more selected, play games, social media or take a walk when compared to the reading. Eventually, the study of Improve Young Learners' Interest in Reading would describe the effective strategies to improve the reading interest through reading aloud, reading the book several times, reading favorite books, and shown many of picture books, by the way of method the use of wall magazine, the use of flash card, and the use of humor to create the reading interest to young learners.

\section{DISCUSSION \\ Definition of Reading}

The discussion of reading has been mentioned in many kinds of literature by many experts. According to Nunan (1989), the definition of reading is a written symbol of the decoding process, that working from the smaller unit such individual letters to the large unit such as words, clauses, and sentences. In additional Haris (1980) expressed that printed or written verbal symbols are the means of interpretation in reading. That means the interaction between the graphic symbols that represent language and cognitive skills, reader skill and knowledge of the world is the result of reading interaction. The readers tried to recreate the meaning intended by the writer occur in this process. Stated of Mackey (1988), an active process is reading. The preliminary expectation about the material is a form from the readers. Thus, do select the fewest, the most productive of the clues by necessary to reject or confirm the expectation. 


\section{Definition of Interest}

To determine as the attitude in working or actively studying becomes a second factor in the interest. If the students have an interest, the learning process will run really well. Thus, felt enjoyed in some activities and contents could pay high attention in situation and condition of interest. Based on Frenshen (1957), accompany of the intellectual's consideration of something, ideas, or the participation in some activity are the condition response of pleasure or satisfaction in interest. Furthermore, Hidi (2006) described that a psychological which occurs during the interaction between the person and their object interest, and it is characterized by the increased of attention, concentration, and effect be a unique motivational variable of interest. It means the student mindset becomes positive in the learning process from the high influence of interest. The more attention and concentration for the students in certain subject matter could create by the positive mindset.

The parallel statement with Hidi (2001), expressed the monitor in establishing all of the activities or information what we want or what we select occur from the interest monitor from some other papers. Thus, we will attend and focused on object or activity that make us interest when we are in the interested. If they have a high interest the students will study in regularly or effectively and they will get the success.

In the personal statement of David (1982), the one that will increase the chance for success is a positive interest. Furthermore, Hurlock (1987) added that the motivation which can convey the people to do and to choose all activities that they want is a result of the interest. It means that the students should increase their interest in learning in order and the teacher should not only transfer the knowledge to the students in the teaching-learning process to make them want to learn harder and have the more motivation to learn.

\section{The Applied of Reading Strategies to Improve the Reading Interest to Young Learners \\ Reading Aloud}

Bredekamp (2011) stated that the foundation for reading success is reading aloud. Mostly, reading aloud to young children is an entertaining manner, promotes language development, and supports the relationship between the child and the family. The role play from the teachers and the members of the family in reading aloud to attract them to learn about the words and language, expand vocabularies, talk about the characters, build the listening skills, plot, settings, and then relate them to their own lives, gain exposure to a variety of writing styles and structures, gain knowledge about a variety of topics, develop the descriptive language, learn to monitor their own behavior, and explore social and moral issues. (Jalongo, 2013).

The teachers and the families that do the read aloud to their children could develop their language literacy skills in the early years and go to the 
kindergarten with the better prepared. For making the meaning is an important experience in reading aloud for children who are interested in listening. To help the children make personal connections is by reading aloud and having good conversations. The children learn to make a connection, construct the meaning, thinking in critically, and develop the reading comprehension can be through by the talk. To know how they comprehend and how they make sense of a book that they were read is by asking them to explain it. The peers can begin to develop a thought process that happens inside the head and respond to the question well.

The research on the effects of reading aloud to children is very varied that the teachers and the members of the family are urged in order to get the greatest benefits in the use of an interactive comprehension strategy. Based on the children matters in how the way the books are shared (McGee \& Schickedanz, 2007, p. 742). From this approach, the teachers and the members of the family use a variety of techniques to engage children in the text and not only carry out the conversations or go often to the small groups (National Center for Family Literacy, 2009). The National Early Literacy Panel has been emphasized that shared the reading strategies when reading aloud to young children gives an impact on the importance of interactive (Shanahan \& Lonigan, 2010).

\section{Reading the Book Several Times}

Proposed by Lane and Wright (2007), reading the book several times is an important way to offers lots of opportunities for the teachers in expressive reading and to practice for modeling fluent. Barrentine (1996) described, the teachers have the opportunity to think about the characters in the story, the plot conflicts and the resolutions, the structure of the text, the images, the story, and the language that the author has chosen to create the characters in the story during they are reading the book for themselves.

\section{Reading Favorite Books}

According to the children reading comprehension, they might broaden their interest in reading beyond of their favorite books, to the different variety and topics of genres that including to the nonfiction, fictions, prose, and poetry. Thus, to help them in creating a positive attitude toward reading the books, and to help them become lifelong lovers of the various books are by allowing the children to self-select their reading genres is a powerful way to motivate them and strengthen their growth in literacy (Willingham, 2015).

\section{Show Many Picture Books}

To reach the children of all the ability levels and appeal to the boys and girls in a multitude of ways are by having picture books with few words. In fact, to enhance the children reading comprehension through by the picture books are very excellent in learning materials. The children 
background knowledge of reading could enhance and could make the good connections between the texts and their prior knowledge by having a look at picture books, signs, posters, charts, and various photos on their regular basis (Lilly \& Fields, 2014).

\section{Method}

\section{The Use of Wall Magazine}

The use of wall magazine is the creative way to create the reading environment for young learners that can be provided in all of the school management. Besides the library school management, wall magazine becomes a media literacy movement for young learners. However, all the teachers and the school management could be used the corners or spaces of the classrooms as a reading atmosphere that could build the children encourage reading habits by utilizing the wall magazine. The environment of the wall magazine will be interested in the creative supervised. The school management and the teachers should be concerned in the purpose of using the wall magazine as an attractive method that could enhance the reading interest for the children. Generally, the children interested increase by visual mode of the text that could attract them in reading. (Dimopoulos, 2003: 3271).

\section{The Use of Flash Card}

The use of flash cards, pictures, and various object images could create a real atmosphere in reading corners. By using flash cards, the children could explore their interest in learning the fabulous languages and vocabulary and could make the teachers as a motivator or facilitator for the children and guide them in communicate other languages from around the outside world. Mostly, flash cards are used in learning drills to increase the memorization of children by repeating. The useful of using flashcards is to enhance the new letters, new words, new syllables, new sounds, and other information for the children. Generally, flash cards are used inside the classroom during learning activities to attract the children enthusiastic. Flash cards are consisting of some cards that contain some pieces of information as words, numbers, or pictures on either one or both sides that usually used in classroom drills activity.

The various vocabulary, historical dates, formula, or any subject matter could be bearing in flash cards that could be learned by guessing, questions and answer format. Thus, flash cards are generally used in meaningful and real-life communicative to guide the children to be more aware of the vast world than they actually see and imagine. This method could give a significant impact on the children in used their ability in communication with others. By introducing the children to the context as well as the relevant vocabulary items that could involve the children in their visual that related to the lesson could help the children engage in the learning process activity. Utilizing the flashcards are more interested in learning session activity and could attract their curiosity to obey in the learning 
process. The attractiveness of flash cards is very interesting in every level of the classroom because flash cards could deliver the content ineffective way that mostly helps the children handy in understanding. However, Flashcards are a great way to motivate the children to keep enthusiastic in learning.

\section{The Use of Humor}

The use of humor in reading interest and reading comprehension for young learners is to facilitate the relaxed and comfortable atmosphere for the children that could bring the great motivation for them and automatically they will enjoy to comprehend the content of the reading section. The use of humor in reading could increase children knowledge intensely. Grotjhan (1957) Humor can be used to express the variety of emotions that would not make the children feel be bored during the learning process. Thus, humor is freedom of self-expression and more capable in understand the surrounding. Everything that learned by humor will be learned well.

Freedom gave humor and humor gave freedom. In the learning session humor gave a beneficial effect for the children. Blumenfeld and Lynne (1986) in learning condition humor transferred the positive effect for the children when the children have difficulties in grasping the material and the explanation that given by the teacher, the children who in confused and not truly understand will judge them self in a group of idiotically. The use of humor is to establish a relaxed situation and avoid the thrilling atmosphere for the less clever group and still encourage them to interest in participate during the discussion with other children.

The use of humor increases student motivation to work actively to achieve their goals. To help the children respected in individual differences, the one way is to use humor is to achieve their tolerance with other children. Palmer (1974) stated that reading needs a lot of practice. It is because to encourage the reading interest for children to read as much as possible becomes a big task and challenging for all the teachers because there is the childrenachievement that has a strict limit that they should get during reading time.

Aside from interesting, humor also enjoyable for the children that give the children-motivation to keep interested in reading. White (2001) show that the teachers and the children could avoid the stress of learning, create a healthy environment for the children, and to gain more attention in the learning session. Thus, Schmitz (2002) explained that the presentation of study using humor become the most integrated and the primary important part in foreign language classes. The use of humor in language courses could create an enjoyable atmosphere, create the contribution in reading, and improve the children proficiency and children comprehension that can addict them to read more and more. 


\section{CONCLUSION}

The conclusion of this study is reading activity becomes the primary focus of English as a Foreign Language teaching-learning in nowadays. Based on the study, it is really clear that the children want to gain more captivating in reading activity that could give the improvement in their reading interest. The children should have a high reading interest and the high of reading motivation to capable in criticizing texts in reading. Mostly, to enhance the reading interest and reading comprehension for the children, the teachers, and the families should intentionally think about how to guide and provide the childreninterest increase with a lot of opportunities. The teachers and the member of the family should show the variety of improving the reading interest that could help them pay attention, maintain, and understand of what they read that could assist and create they're independently that also make them become an intelligent reader in nowadays. Build the meaning of the children while reading could require the intellectual work, the teachers and the family member who get the interest of their children may be more effective in helping them in developing a good reading and comprehension skills. The reading interest and reading comprehension skills could enrich children or young learners in language skills. The children-achievement in language skills especially in reading could be a great road to success in reading.

\section{REFERENCE}

Astuti, Kristha. 2015. The Use of Flash Cards to Improve Young Learners' Interest in Learning English. Semarang: Universitas Negeri Semarang

Junisy, Muhammad. 2017. Thesis: The Use of Humor Text to Motivate the Students in Reading Interest at Darul Ihsan Boarding School. Banda Aceh: Ar-Ranir State Islamic University

O'Flynn, Kayleigh. 2016. Students' Reading Interests Impact on Reading Comprehension Abilities. Ralph C. Wilson, Jr. School of Education. NewYork: St. John Fisher College

Ortllieb, Evan T. 2010. Beyond Just Books: Sparking Children's Interest in Reading. International Journal of Educatio. Texas: Texas A\&M University. ISSN 1948-5476 2010, Vol. 2, No. 2.

Park, Mi Hwa., and Chhanda Islam. 2016. Strategies to Enhance Kindergarten Children's Reading Comprehension. International Journal of Language and Linguistics. Murray: Murray State University. Vol. 3, No. 2.

Sarah, Hani Maruta. 2017. The Implementation of Interactive Read Aloud in Teaching English to EFL Young Learners. Journal of English and Education. Indonesia: Indonesia University of Education Indonesia. Vol. 5 No. 2, October 2017, pp 112-119

Susan M. Ebbers. 2011. How to Generate Interest So Reading Comprehension Improves. Comprehension, Reading. 
California: University of

California

Sutarti, Tatik. 2017. Efforts to Increase

Students Reading Interest on

Educational Reference through

Classical Guidance and

Counseling Experiential

Learning Model. Journal of

Education, Teaching and Learning.

Indonesia: STKIP PGRI -

Pacitan. Volume 2 Number 1. Page

118-123 p-ISSN: 2477-5924 e-

ISSN: $2477-4878$. 